\title{
Lead concentration in the muscles of slaughtered buffalos in northwest regions of Iran
}

\author{
Razzagh Mahmoudi ${ }^{1}$, Bahareh Rahimi ${ }^{2}$, Parviz Hassanzadeh ${ }^{3}$, Peyman Ghajarbeygi ${ }^{4}$, Babak Pakbin ${ }^{5}$
}

${ }^{1}$ Associate Professor, Department of Food Hygiene and Aquatics, University of Tabriz, Tabriz, Iran

${ }^{2}$ D.V.M. Department of Food Hygiene and Aquatics, Faculty of Veterinary Medicine, University of Tabriz, Tabriz, Iran

${ }^{3}$ Assistant Professor, Department of Food Hygiene and Aquatics, University of Tabriz, Tabriz, Iran

${ }^{4}$ Assistant Professor, Health Products Safety Research Center, Qazvin University of Medical Sciences, Qazvin, Iran

${ }^{5} \mathrm{PhD}$ Student, Department of Food Hygiene and Quality Control, Faculty of Veterinary Medicine, University of Tehran, Tehran, Iran

Type of article: Original

\begin{abstract}
Background: The topic of food safety has become a major public health issue worldwide. Over recent decades, the growing concern for food safety has brought about greater research regarding the risks associated with the consumption of produce that has been contaminated by pesticides, heavy metals and/or toxins.

Objective: The study was conducted to determine the concentration of $\mathrm{Pb}$ in the muscle of buffalos slaughtered in the northwest regions of Iran (Ardabil, Urmia and Tabriz cities).

Methods: The present was a descriptive cross-sectional study in the northwest regions of Iran during 2013 to 2014. A total of 30 muscle samples from individual buffalos were analyzed for Pb concentrations using Atomic Absorption Spectrophotometer (ASS). Statistical analysis was performed using SPSS 17.0. All results were computed as mean standard deviation and subjected to one-way analysis of variance to establish whether the differences in $\mathrm{Pb}$ concentrations in meat samples from different cities were significant or not. The Statistical significance was determined at $\mathrm{p}<0.05$.

Results: The results showed that the mean concentration of $\mathrm{Pb}$ in muscle samples were measured $0.043 \pm 0.035$ ppm. The highest $\mathrm{Pb}$ concentration $(0.11 \mathrm{ppm})$ was detected in the buffalo muscle samples from Urmia city. In total, 25 muscle samples $(80.33 \%)$ were contaminated with $\mathrm{Pb}$ and concentration of $\mathrm{Pb}$ in $3.33 \%$ of contaminated samples exceeded the permissible limits advised by the European Commission (EC) $(0.1 \mathrm{ppm})$.

Conclusion: We recommend identifying $\mathrm{Pb}$ sources in order to eliminate or control $\mathrm{Pb}$ contamination of food, and monitor environmental exposures and hazards to prevent lead poisoning.

Keywords: Buffalo, Muscles, Pb, Atomic Absorption Spectrophotometer, Iran
\end{abstract}

\section{Introduction}

Although there is great concern for food-borne illnesses caused by consumption of produce contaminated with microorganisms and/or their toxins, there are additional health hazards from produce contaminated with other toxins, including fungal toxins and heavy metals that could also lead to acute poisoning and long-term health problems (1). Attention to the ramifications associated with heavy metal contamination is of the utmost concern. In general, heavy metals are nonbiodegradable, having extensive biological half-lives and the potential to accumulate in different body organs, which can ultimately lead to unwanted side effects (2-4). Several studies have indicated that heavy metals, such as $\mathrm{Cd}, \mathrm{Pb}$, and $\mathrm{Cr}$, have the ability to accumulate in the muscles of many animals such as cows, sheep and buffalos (5-7). The findings of Massanyi et al. confirmed that $\mathrm{Cd}$ and $\mathrm{Pb}$ have the ability of accumulation in sheep muscles, but concentration of heavy metals in the muscles are lower in comparison with

\section{Corresponding author:}

Associate Professor Dr. Razzagh Mahmoudi, Department of Food Hygiene and Aquatics, University of Tabriz, Tabriz, Iran. Tel: +98.9127868571, Fax:+98.2833345862, email address: r.mahmodi@yahoo.com

Received: May 09, 2017, Accepted: August 20, 2017, Published: January 2018

iThenticate screening: August 21, 2017, English editing: January 14, 2018, Quality control: January 15, 2018

This article has been reviewed / commented by three experts

(C) 2018 The Authors. This is an open access article under the terms of the Creative Commons Attribution-NonCommercialNoDerivs License, which permits use and distribution in any medium, provided the original work is properly cited, the use is non-commercial and no modifications or adaptations are made. 
kidneys and livers (6). Though caution is exercised to ensure that a very healthy cow is processed for consumption, a cow with high levels of toxic metals may not show any obvious symptoms of illness and thereby possess hidden potential health risk to humans (5). Meat of ruminant animals such as cattle, sheep and buffalo are very rich of microelements and they are convenient sources for microelements. The chemical composition of meat heavily depends on the amount and type of food they are consuming. Due to the water and grazing of buffalos in pastures with contaminated soil, higher concentrations of metals are found in their body and products including meat and milk (8). There are various elements such as $\mathrm{Pb}$, cadmium, arsenic and mercury which are non-essential and are toxic, even at low concentrations. Others, such as zinc and copper are vital to the composition of the human body; they play significant roles in the various biological systems. When their intake exceeds the body's limit, however, they can be harmful and can exert toxic effects (9). These non-essential heavy metals are toxic to cardiovascular, hematopoietic, neural, gastrointestinal and immunological systems (10). They can also cause kidney dysfunction, liver toxicity, anemia, cancer and Alzheimer disease (11). The risks associated with the exposure of humans to heavy metals present in food with animal origin, have aroused widespread concern in human health. Hence contamination of food with heavy metals is a serious threat because of their toxicity, bioaccumulation and biomagnifications in the food chain. Therefore, the aim of the present study was to determine the concentrations of $\mathrm{Pb}$ in the buffalo meat samples slaughtered in northwest regions of Iran (including: Ardabil, Urmia and Tabriz cities).

\section{Material and Methods}

\subsection{Sampling}

A total of 30 buffalo muscle samples (slaughtered in northwest regions of Iran including Ardabil, Urmia and Tabriz city) were collected. The samples were collected in polyethylene bags (All estimations were made in triplicates) and transferred to the food quality control laboratory at the Faculty of Veterinary Medicine, Tabriz University for analysis. The study was carried out from May 2013 to April 2014.

\subsection{Sample preparation}

In order to determine $\mathrm{Pb}$ concentration, the collected samples were decomposed by wet digestion method.

An amount of $2 \mathrm{gr}$ from each muscle sample was added into the digestion flask containing nitric acid $(1 \mathrm{~N}$, Trace Metal grade HNO3; Fisher Scientific) and digestion was performed at $80^{\circ} \mathrm{C}$ for $4 \mathrm{~h}$. At the end of digestion, the supernatant was removed and its volume was measured to calculate the concentration of $\mathrm{Pb}(12)$.

\subsection{Elemental analysis of samples}

To determine the concentration of $\mathrm{Pb}$ in buffalo meat samples, tests were carried out directly in each of the final solutions using Biotech Engineering Ltd., UK- Phoenix - 986 Atomic Absorption Spectroscopy (AAS) (12).

\subsection{Statistical analyses}

For each meat sample, three measurements were undertaken. Data were analyzed by SPSS 17.0 (SPSS Inc., Chicago, IL, USA) using descriptive statistics such as Mean, Standard Deviation, and inferential statistical analyses including one-way analysis of variance (ANOVA) to establish whether the differences in Pb concentrations in meat samples from different cities were significant or not. The Statistical significance was determined at $\mathrm{P}<0.05$.

\section{Results}

The concentration of $\mathrm{Pb}$ in buffalo muscle samples was measured and presented in Table 1 . The $\mathrm{Pb}$ levels ranged between 0.002-0.116 ppm. The highest mean concentration of $\mathrm{Pb}(0.061 \pm 0.031 \mathrm{ppm})$ was measured in the buffalo muscle samples slaughtered in Urmia city ( $<<0.05$; Figure 1 ). The $\mathrm{Pb}$ was detected in $80.33 \%$ of the buffalo muscle samples, and the level of the $\mathrm{Pb}$ in $3.33 \%$ of contaminated samples exceeded the permissible limits defined by EC (0.1 ppm) (13).

Table 1. Pb level in water buffalo muscles slaughtered in North West Region, Iran

\begin{tabular}{|l|l|l|l|l|l|l|}
\hline $\begin{array}{l}\text { Sampling } \\
\text { region }\end{array}$ & $\begin{array}{l}\text { No. of samples } \\
\text { analyzed }\end{array}$ & $\begin{array}{l}\text { No. of samples with } \\
\text { measurable PB }\end{array}$ & $\begin{array}{l}\text { \% of samples with } \\
\text { measurable Pb }\end{array}$ & $\begin{array}{l}\text { Pb concentration } \\
\text { (Mean } \pm \text { SD) ppm }\end{array}$ & Min-Max & $\begin{array}{l}\text { Exceed legal } \\
\text { limit } \mathrm{n}(\%)\end{array}$ \\
\hline Urmia & 18 & 17 & 94.44 & $0.061 \pm 0.031^{\mathrm{a}}$ & $0.024-0.116$ & $1(5.88)$ \\
\hline Ardabil & 7 & 4 & 57.14 & $0.015 \pm 0.024^{\mathrm{b}}$ & $0.002-0.063$ & $0(0)$ \\
\hline Tabriz & 5 & 4 & 80 & $0.024 \pm 0.019^{\mathrm{a}, \mathrm{b}}$ & $0.025-0.046$ & $0(0)$ \\
\hline Total & 30 & 25 & 80.33 & $0.043 \pm 0.035$ & $0.002-0.116$ & $1(3.33)$ \\
\hline
\end{tabular}

Means \pm SD in the same column with different letters are significantly different $(\mathrm{p}<0.05)$. 


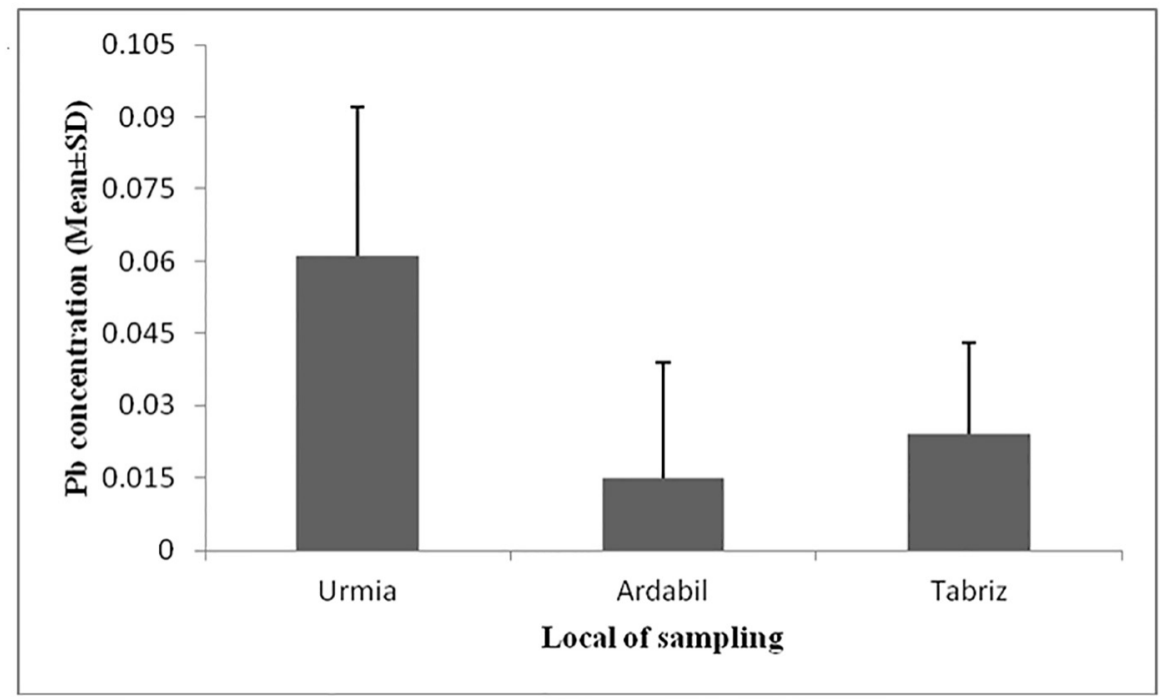

Figure 1. Comparison of $\mathrm{Pb}$ concentration $(\mathrm{Mean} \pm \mathrm{SD})$ in buffalo meat samples from different cities

\section{Discussion}

The human diet is the main entry route of most elements into the body. The source of metals is the amalgamation of fossil fuels, mining industries, waste disposal, and domestic sewage in the environment. Fertilizers and pesticides used in industrial agriculture, farming and forestry also contribute to the metal content in the environment (14). According to the results of the present study, $\mathrm{Pb}$ levels in the most meats samples (except one sample belonging to Urmia) were lower than the permissible limits defined by the EC for human health (0.1 ppm) (13). The main edible part of domestic animals is the muscle, but human health can be directly affected if it carries metals beyond the standards. For this reason, most guidelines establish an allowable level of concentration limit to toxic elements in this organ (15). The maximum $\mathrm{Pb}$ concentration for meat of bovine, sheep, pig and poultry has been proposed as 0.1 ppm (13). It is clear from the results of the present study that $\mathrm{Pb}$ concentration in the muscle of slaughtered buffalo from northwest regions of Iran was generally lower than the maximum acceptable concentration by the EC. Moreover, $\mathrm{Pb}$ was detected in $80.33 \%$ of the buffalo muscle samples and the level of the $\mathrm{Pb}$ in one contaminated sample (3.33\%) exceeded the permissible limits defined by the EC. Also, the highest $\mathrm{Pb}$ mean concentration was observed in Urmia, while Ardabil samples had the lowest concentration among all of the samples (Figure 1). In the studied area, toxic breeding areas such as industrial and chemical factories may be the main sources of pollution, which will result in the contamination of feed, water, and indeed the air inhaled by the animals, in addition to the manufacturing processes in the countries from where the animals were imported (13). Several researches have been conducted in many countries to determine the levels of metals in animal products (16-18). Gonzalez-Weller et al. reported that $\mathrm{Cd}$ and $\mathrm{Pb}$ concentrations in meat products exceeded the recommended limits (17). Levels of $\mathrm{Pb}$ in buffalo muscles in the present study were lower than of $\mathrm{Cd}$ concentration in sheep muscles from Falavarjan abattoir, Iran (19).

The results of metal concentrations in the muscles of slaughtered cows, calves, and sheep in Sanandaj, Iran indicate that the $\mathrm{Pb}, \mathrm{Cr}$ and $\mathrm{Cd}$ levels were higher than of $\mathrm{Pb}$ concentration in buffalo muscle in the present study (20). Moreover, $\mathrm{Pb}$ concentrations in buffalo meat examined in the present study were lower than those in sheep and cattle of Palestinian farms (21), in sheep of Egypt (16), and in cows and sheep of Borno State, Nigeria (8). Toxic elements can be very harmful even at low concentration when ingested over a long time period. $\mathrm{Pb}$ is a non-essential element in foods and natural waters, and it accumulates in the kidneys and liver (22). The WHO (2000) suggests maximum tolerable weekly intakes for lead is $25 \mu \mathrm{g} / \mathrm{Kg}$ bw per week (23). In many Asian countries such as Iran, the average daily consumption of red meat is about 50-90 grams. Based on the results of the present study, the mean $\mathrm{Pb}$ content of buffalo muscle samples were $0.043 \mathrm{ppm}$. Therefore, consuming $50 \mathrm{~g}$ per day of muscle provides 0.02 $\mathrm{ppm} \mathrm{Pb}$ in a day. Therefore, a person with an average body weight of $60 \mathrm{~kg}$ will receive $\mathrm{Pb}$ lower than defined limit $\mathrm{of} \mathrm{Pb}$. Although the contamination of animal feed by toxic metals cannot be entirely avoided given the prevalence of these pollutants in the environment, minimizing of $\mathrm{Pb}$ contamination in food is necessary with the aim of reducing both direct effects on animal health and indirect effects on human health. 


\section{Conclusions}

The results of this study indicated that $\mathrm{Pb}$ concentrations in most buffalo muscles of three studied regions from northwest regions of Iran are lower than the levels of concern for human consumption. In other words, their levels in the muscle, indicate that the risk of these metals for consumers' health is low.

\section{Acknowledgments:}

This study was part of a DVM thesis approved by the University of Tabriz and thereby it is necessary to thank the Research Council of the University of Tabriz for the approval and funding of this thesis.

\section{Conflict of Interest:}

There is no conflict of interest to be declared.

\section{Authors' contributions:}

All authors contributed to this project and article equally. All authors read and approved the final manuscript.

\section{References:}

1) Musaiger AO, Al-jedah JS, D'souza R. Occurrence of contaminants in foods commonly consumed in Bahrain. Food Control. 2008; 19: 854-61. doi: 10.1016/j.foodcont.2007.08.011.

2) Banerjee D, Kuila P, Ganguli A, Das D, Mukherjee S, Ray L. Heavy metal contamination in vegetables collected from market sites of Kolkata, India. Electronic Journal of Environmental, Agricultural and Food Chemistry. 2011; 10(4): 2160-5.

3) Jarup L. Hazards of heavy metal contamination. Br Med Bull. 2003; 68: 167-82. doi: 10.1093/bmb/ldg032. PMID: 14757716.

4) Sathawara NG, Parikh DJ, Agarwal YK. Essential heavy metals in environmental samples from western India. Bull Environ Contam Toxicol. 2004; 73: 264-9. doi: 10.1007/s00128-004-0490-1. PMID: 15389343.

5) Jukna C, Jukna V, Siugzdaite J. Determination of heavy metals in viscera and muscles of cattle. Bulgarian Journal of Veterinary Medicine. 2006; 9(1): 35-41.

6) Massanyi P, Nad P, Toman R, Kovacik J. Concentrations of cadmium, lead, nickel, copper and zinc in various muscles of sheep. Bodenkultur. 2001; 52(3): 255-8.

7) Nwude D, Okoye P, Babayemi J. Heavy metal levels in animal muscle tissue: a case study of Nigerian raised cattle. Research Journal of Applied Sciences 2010; 5(2): 146-50. doi: 10.3923/rjasci.2010.146.150.

8) Akan J, Abdulrahman F, Sodipo O, Chiroma Y. Distribution of heavy metals in the liver, kidney and meat of beef, mutton, caprine and chicken from Kasuwan Shanu market in Maiduguri Metropolis, Borno State, Nigeria. Research Journal of Applied Sciences, Engineering and Technology. 2010; 2( 8): 743-8.

9) Celik U, Oehlenschlager J. High contents of cadmium, lead, zinc and copper in popular fishery products sold in Turkish supermarkets. Food Control. 2007; 18(3): 258-61. doi: 10.1016/j.foodcont.2005.10.004.

10) Zarei M, Eskandari MH, Pakfetrat S. Determination of heavy metals content of refined table salts. American-Eurasian Journal of Toxicological Sciences. 2011; 3(2): 59-62.

11) Damek-Poprawa M, Sawicka-Kapusta K. Histopathological changes in the liver, kidneys, and testes of bank voles environmentally exposed to heavy metal emissions from the steelworks and zinc smelter in Poland. Environmental Research. 2004; 96(1): 72-8. doi: 10.1016/j.envres.2004.02.003.PMID: 15261786.

12) Playle RC, Dixon DG, Burnison K. Copper and cadmium binding to fish gill: modification by dissolved organic carbon and synthetic ligands. Canadian Journal of Fisheries and Aquatic Sciences. 1993; 50: 266777. doi: 10.1139/f93-290.

13) European Commission EC. Reports on tasks for scientific cooperation. "Assessment of the dietary exposure to arsenic, cadmium, lead and mercury of the population of the EU member states", Report of experts participating in Task 3.2.11, March 2004.

14) Hussain RM, Ebraheem MK, Moker HM. Assesment of heavy metals ( $\mathrm{Cd}, \mathrm{Pb}$ and $\mathrm{Zn}$ ) content in liver of chicken available in the local markets of basrah city, Iraq. Basrah Journal of Veterinary Research. 2012; 11(1): 43-51.

15) Yazdi RB, Ebrahimpour M, Mansouri B, Rezaei MR, Babaei H. Contamination of metals in tissues of Ctenopharyngodon idella and Perca fluviatilis, from Anzali Wetland, Iran. Bulletin of environmental contamination and toxicology. 2012; 89(4): 831-5. doi: 10.1007/s00128-012-0795-4. PMID: 22918320.

16) Abou-Arab A. Heavy metal contents in Egyptian meat and the role of detergent washing on their levels. Food and Chemical Toxicology. 2001; 39(6): 593-9. doi: 10.1016/S0278-6915(00)00176-9. 
17) González-Weller D, Karlsson L, Caballero A, Hernández F, Gutiérrez A, González-Iglesias T, et al. Lead and cadmium in meat and meat products consumed by the population in Tenerife Island, Spain. Food additives and Contaminants. 2006; 23(8): 757-63. doi: 10.1080/02652030600758142. PMID: 16807203.

18) Rudy M. The analysis of correlations between the age and the level of bioaccumulation of heavy metals in tissues and the chemical composition of sheep meat from the region in SE Poland. Food and Chemical Toxicology. 2009; 47(6): 1117-22. doi: 10.1016/j.fct.2009.01.035. PMID: 19425230.

19) Kazemeini H, Rahimi E, Kharrattaherdel A, Nozarpour N, Ebadi A. Cadmium concentration in muscle, liver and kidney of sheep slaughtered in Falavarjan abattoir, Iran. Toxicology and industrial health. 2010; 26(5): 259-63. doi: 10.1177/0748233710364963. PMID: 20305051.

20) Ariyaee M, Mansouri B, Rezaei Z. The results of Metal Concentrations in the Muscles of Slaughtered Cows, Calves, and Sheep in Sanandaj City, Iran. Iranian Journal of Toxicology. 2015; 9(28): 1235-8.

21) Swaileh K, Abdulkhaliq A, Hussein R, Matani M. Distribution of toxic metals in organs of local cattle, sheep, goat and poultry from the West Bank, Palestinian Authority. Bulletin of environmental contamination and toxicology. 2009; 83(2): 265-8. doi: 10.1007/s00128-009-9704-x. PMID: 19290446.

22) Belitz HD, Grosch W, Schieberle P. Lehrbuch der Lebensmittelchemie. Berlin: Springer: 2001. doi: 10.1007/978-3-662-08302-4.

23) World Health Organization. Safety evaluation of certain food additives and contaminants. WHO food additives series no. 44. Cambridge: Cambridge University Press; 2000. 